\title{
Articulatory Analysis of Palatalization in Anaang
}

\author{
Mfon Brownson Ekpe \\ English Department, College of Humanities \\ Redeemer's University, Mowe, Nigeria \\ E-mail:mfobrown@yahoo.com
}

Received: 01-08-2013

Accepted: 03-09-2013

Published: 01-11-2013

doi:10.7575/aiac.ijalel.v.2n.6p.155

URL: http://dx.doi.org/10.7575/aiac.ijalel.v.2n.6p.155

\begin{abstract}
This paper examines the Articulatory features of palatalisation in the phonology of Anaang language. Anaang is a developing language spoken by the Anaang people in Akwa Ibom State of Nigeria. Genetically, Anaang is a Lower Cross Language of the Benue-Congo sub-family of the Niger-Congo Language Phylum. The objectives of the study are to investigate the articulatory features of Anaang and how palatalisation is formed in the language. The population is made of sixteen informants, two from each of the eight local government areas in Anaang speaking areas. Collection of data is based on interviews, participant observation and personal interaction with the informants. In achieving this, fifty items were used from SIL Comparative African Wordlists. Interviews were both formally and informally recorded in a digital midget. Formally, the recordings were done on the knowledge of the informants who were asked to pronounce words in Anaang. Informally, data were recorded unknowingly to the informants in social gatherings. Articulatory Model by Browman \& Goldstein (1990) is adopted as the theoretical frame for the analysis. The theory recognizes gestures as abstract, discreet and dynamically defined units which are invariant, but overlap in time due to their internal spatio-temporal organisation. The findings of the investigation show that palatalisation in Anaang is formed when a non-palatal consonant is followed be a high front vowel [i]. For palatalisation to occur there must be a target which is usually a non palatal consonant and a trigger which must be a high front vowel. Palatalisation in Anaang involves partial assimilation as there is no total shift in place feature, but an overlap in internal spatio-temporal organisation. Though articulatory examination is not so accurate and empirical it prised open further research into acoustic investigation which is more scientific and reliable.
\end{abstract}

Keywords: Articulatory, Phonology, Coarticulation, Palatalisation, Anaang language

\section{Introduction}

This paper focuses on the articulatory investigation of Anaang palatalisation with the view of establishing its patterns and how they are formed. In achieving this, the language of study is investigated into as well as its demography and genetic affiliation. The method of population selection, data collection, theoretical framework, literature review, data presentation, description of data as well as findings of analysis is discussed.

\section{The Anaang Language}

Anaang /ánà:y/ is a language spoken by the Anaang people in Akwa Ibom State of Nigeria. It constitutes the second largest language spoken in Akwa Ibom after Ibibio language. It is the fourth largest language in Nigeria after Hausa, Yoruba and Igbo. The speakers of Anaang language according to the 2006 population census are 1.8 million and they occupy a total landmass of 2.73 square kilometers of Akwa Ibom State. Anaang is made up of homogenous group of people with common linguistic heritage and it is used as the first language $\left(\mathrm{L}_{1}\right)$ by the inhabitants of Abak, Oruk-Anam, Ukanafun, Essien-Udim, Ikot-Ekpene, Obot-Akara, Etim-Ekpo and Ika Local Council Division (LCD) of Akwa Ibom State. The inhabitants of Anaang language speech community occupy the North-Western part of Akwa Ibom State. They are bounded by the Igbo Speaking group of Abia State in the North, the Ogoni speakers of River State in the West, the Ibibio speakers in the South, East and North.

Genetically, Anaang is a Lower Cross Language (LCL) of the Benue-Congo sub-family of the Niger-Congo Language Phylum, (Greenberg 1963). Williamson (1989) classifies Anaang language as a cluster in the Lower Cross division of the Delta Cross branch within Cross River of Benue-Congo. Connell (1991) puts Anaang-Ibibio-Efik and Ukwa group as Central Lower Cross of the Lower Cross arm of Benue-Congo. Essien (1987) and Urua (1994) group the AnaangIbibio-Efik as a dialect cluster among several other varieties spoken in Akwa Ibom State. These entire classifications group Anaang with Ibibio and Efik as a cluster of language which share close linguistic affinity with each other.

\section{Research Methodology/Instruments}

The population of study comprises sixteen informants randomly selected, two each from the eight local government speaking areas of Anaang. Collection of data is based on interviews, participant observation and personal interaction with the informants. In achieving this, fifty items were extracted from SIL Comparative African Wordlists. Interviews 
were both formally and informally recorded in a digital midget. Formally, the recordings were done on the knowledge of the informants who were asked to pronounce words in Anaang. Informally, data were recorded without the knowledge of the informants mostly during personal interaction and in social gathering, which afterwards the lexical items with the investigated features were extracted to form parts of the corpus of study. The investigated features and patterns are described articulatorily.

This descriptive study on palatalisation of Anaang is a major contribution to articulatory phonological theory. An analysis of this nature provides empirical evidence on some complicated assimilatory processes. It also provides data for documentation of Anaang to prevent it from possible extinction in the near future.

\title{
3.1 Theoretical Framework
}

Browman \& Goldstein (1990) Articulatory model is adopted as the theoretical framework for the study. Browman \& Goldstein (1990) say that linguistic forms are expressed in both space and time as different articulators produce constrictions at different points along the vocal tract as they move in real time. While the spatial aspect is taken care of by non-gestural phonological theories, with reference to places of articulation, the temporal aspect is being addressed primarily through static linear arrangement and 'spreading' of features in that adjacent segments share a feature. Proponents of articulatory model are of the opinion that phonological processes such as consonantal assimilation and vocalic epenthesis are best explained by making reference to gestures and their coordination as speech unfolds through time. Thus, phonological representation must contain information about temporal structure and phonological processes must make reference to temporal interaction in a more direct way, (Byrd 1996b, Kochetov 2002, Gafos 2002, Davidson 2004). For this reason, it is necessary to discuss Anaang palatalization patterns through gestural model as palatalization result from the coordination of consonantal and vocalic gestures. In articulatory model the 'gesture' is the pivot of phonological contrast with an inherent spatial and temporal structure, (Brownman and Goldstein 1990, Gafos 2002). As such gestures are abstract, discreet and dynamically defined units which are invariant, but can overlap in time due to their internal-temporal structure. The dynamical aspect of gestures results from the fact that they represent continuous articulatory trajectories. Each lexical item is composed of a constellation of pre-specified gestures that are phased (timed) in particular ways with respect to each other. As such lexical items contrastiveness could result from either gestural composition, that is, whether a particular gesture is present or absent or due to inter-gestural timing. Each gesture is specified with reference to different level vocal tract configurations that involve the various sets of articulators (e.g. upper and lower lip, jaw) as well as constriction location (CL) and constriction degree (CD). These specifications come together for a particular speech task; for instance the lip closure in the articulation of bilabial sounds. Gestures also have a degree of stiffness (duration) in terms of time taken for the time variables to reach its target (Browman \& Goldstein (1989:208). The exact duration of each gesture is not important and cannot be articulatorily quantified as duration is an inherent property of each gesture. According to (Browman \& Goldstein (1990) in articulatory phonology reference to timing refers to coordination of gestures which is expressed as a degree of temporal overlap. Three articulatory sub-system is recognised in articulatory phonology which are oral, velic and laryngeal or glottal. The oral articulatory subsystem is the gesture that is relevant to the analysis of palatalisation. Gafos (2002), Browman \& Goldstein (1991) present oral tract variable and their articulatory sets as shown in 1 below;

\section{AP Variables and Articulator Sets Tract Variables}

$\begin{array}{ll}\text { i. } & \text { Lip Protrusion } \\ \text { ii. } & \text { Lip Aperture } \\ \text { iii. } & \text { Tongue Tip Constriction Location (TTCL) } \\ \text { iv. } & \text { Tongue Tip Constriction Degree (TTCD) } \\ \text { v. } & \text { Tongue Body Constriction Location (TBCL) } \\ \text { vi. } & \text { Tongue Body Constriction Degree (TBCD) } \\ \text { vii. } & \text { Velic Aperture } \\ \text { viii. } & \text { Glottal aperture }\end{array}$

\author{
Articulator Sets \\ upper and lower lips, jaw \\ upper and lower lips, jaw \\ tongue tip, body, jaw \\ tongue tip, body, jaw \\ tongue body, jaw \\ tongue body, jaw \\ velum \\ glottis
}

The first four affects oral articulatory system and are pairs of variables like lip protrusion and lip aperture, tip tongue location and degree etc. Constriction location (CL) is synonymous to places of articulation (Ladefoged 1989) while Constriction degree (CD) indicates distinction in different kinds of obstruents, and between obstruents and sonorants.

Since palatalization is a product of assimilatory effect, there is no clear demarcation between one sound and another as far as they are articulated as a string of sounds that form a word. The feature of one sound must definitely intrude and blend into the precinct of another sound resulting in overlapping gesture. Gafos (2002) says when gestures overlap, each gesture has temporal landmarks such as onset of movement, achievement of target location when maximal constriction is reached, the centre of the constriction phase, the articulatory release of constriction and the release offset, when the articulator ceases to be under active control. Thus, in Anaang word, $/ \mathrm{mìn} / \quad$ [m $\left.\mathrm{m}^{\mathrm{j}} \mathrm{in}\right]$ 'squeeze out', the onset gesture for $[\mathrm{m}]$ starts when the lip articulators begin the movement towards the constriction location, the target is reached at lip closure, the apex temporal landmark is reached when the lips are closed. Lip opening marks the release of the gesture and the release offset occurs as the lips stop to be under active control. This release offset automatically blends into and forms the onset of the next sound. This is why Bateman (2007:194) posits that gestures are abstract 
phonological units with an internal spatio-temporal organisation which in turn make reference directly to physical implementation by articulators. This shows that gestures are both phonological representation and phonetic representation, because the actual segments at the surface may be different from its actual realisation. The differences can only be explained through phonological process like assimilation which palatalisation is a part.

\subsection{Articulatory Phonology}

Phonology studies how the segments and the suprasegments are structured to function in a language. Individual languages have rules that govern the structuring of these components. The basic raw data for the study of phonology is phonetics. Phonetics deals with the study of how speech signals are produced, transmitted and perceived. These occupations of phonetics thereby group phonetics into articulatory, acoustic and auditory. Articulatory aspect which our investigation focuses is the study of how speech sounds and non-sounds are produced by the human speech articulators. These articulators are commonly called 'organs of speech'. Its successful manipulation enables a native speaker to explore the resources of his language effectively. Therefore, articulatory phonetics deals with the categorization and classification of the features of speech production. Speech production is manifested mostly through the activities of the tongue and the lips movements. According to Johnson (2006:1) these lip and tongue gesture involves pushing of air out of the lungs while producing audible noise. This makes the respiratory system a power source for speech production by pulsating air out of the lungs. The pulsated air is modulated by the articulators to produce the desired sound. These sounds are classified as consonants and vowels which we would not describe in details except those sounds that have direct impact on our subject of focus: 'palatalisation'. Palatalisation involves interaction of some consonants and vowels in a language, which however is constrained by the phonotactic of that language. The location of palatalisation amongst the articulators is the region behind the alveolar ridge through the hard to the soft palate as shown in figure 1 below.

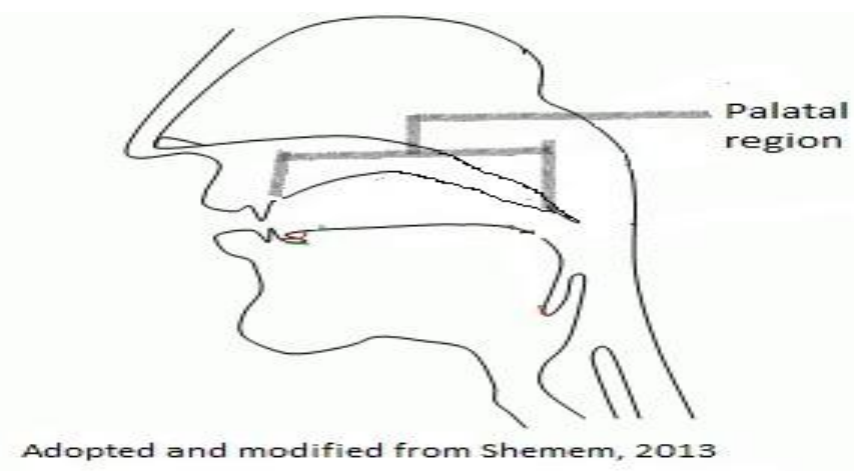

Figure 1. Localisation of Palatalisation

The area indicated as palatal region covers the alveo-palatal and palatal places of articulation. Any shift in the primary place of articulation of a sound towards this region constitutes palatalisation. The shift could be from the front or from the back converging within the alveo-palatal; hard palate and soft palate. It is necessary to say here that palatal sounds are different from palatalised sounds. Sounds that have their primary place articulation at the palatal region are the palatal sounds while the sounds that have their primary places of articulation at other areas other than the palatal region but capture palatal features constitute palatalised sounds. It is interesting to note that palatalisation can not affect palatal sounds because they are inherently palatalised. Egbokhare (2002:49) says, it is physiologically impossible for palatal sounds to be palatalised, because the same articulators cannot possibly maintain varying degree of stricture simultaneously. Therefore, it is only non-palatal sounds that are palatalised. Consider the examples in 2 below in Anaang.

\begin{tabular}{|c|c|}
\hline & \\
\hline ii. /tyin/ & [tyin] \\
\hline iii. /dí & {$\left[\mathrm{d}^{\mathrm{j}}{ }^{\prime} \mathrm{w}^{\mathrm{j}}{ }^{\prime}\right]$} \\
\hline
\end{tabular}

In $2 \mathrm{i}$-ii, the affricatives $/ \mathrm{t} /, / \mathrm{d} /$ are inherently palatal phonemes, as such are not palatalised, while the alveolar $/ \mathrm{d} /$ and bilabial $/ \mathrm{m} /$ in iii -iv are palatalised.

In palatalization there must be a 'trigger' and a 'target'. The trigger is always the vowel while the target: the consonants. The targets are considered in terms of places of articulation such as bilabial, velar, while trigger is determined by the height and 'frontness' of the tongue. According to Bateman (2007:6) the configuration of the vocal tract, the speech articulators, the places of articulation of different consonants and the palatalization triggers allow us to make certain predictions about possible full palatalisation outcome. For instance in Anaang the target consonant for example /t/ which is an alveolar (coronal) is predicted to be partially palatalised as it is articulated with the tongue, the same articulator used for the trigger vowel /i/. For example in the word /típ/ $\rightarrow$ [t'íp] 'make a hole'. The trigger shot 
the target at a close range as compared to $/ \mathrm{kp} / \mathrm{in} / \mathrm{kpi} / \rightarrow \quad\left[\mathrm{kp}^{\mathrm{ji}}\right]$ 'cut' where the target is labial, and the shot is long range considering the spatial location between the target and the trigger.

\subsection{Palatalisation}

Palatalisation is a secondary articulation which involves addition of the glide $/ \mathrm{j} /$ to a consonant. This is achieved by the body of the tongue being raised to constrict the vocal tract in a stricture of open approximation at the palatal location (Laver 1994:320). Generally, in palatalisation a non palatal segment in the environment of a following high front vowel picks the features of palatal sound. This is a secondary articulation that involves the movement of the front upper surface of the tongue towards the hard palate at the top of the mouth. Palatalisation of speech sounds may occur when a consonant sound is followed by a closed front vowel such as /i/. Adetugbo (1993: 40) says sounds are said to have palatalisation as their secondary articulation when a sound, which normally is, said either at the back of the mouth, or further front in the mouth before the hard palate is changed so that they move forwards or backwards respectively towards the hard palate. Egbokhare (2002) says palatalisation occurs when in the production of non-palatal sounds, there may be a modification which adds an i-colouring to the sound. This is a secondary articulation that involves a superimposition of the raising of the front of the tongue towards the hard palate. It involves raising the tip and blade of the tongue to a high front close to the anterior part of the hard palate region, as for an [i] vowel, (Clark \& Yallop, 1990:200). Johnson (2006:234) defines palatalisation as the addition of a high front gesture, like that in [i], to another gesture. He adds that the term describes a process in which the primary gesture is changed so that it becomes more palatal. Thus, sounds are said to be palatalized if the point of articulation moves towards the palatal region. For example, the Anaang $/ \mathrm{kp} /$ in $/ \mathrm{kpì} / \rightarrow\left[\mathrm{kp}^{\mathrm{j}} \mathrm{i}\right]$ 'cut', is palatalized because instead of the labial contact of the kind that occurs in $/ \mathrm{kpá} / \rightarrow$ [kpá] 'die', the place of articulation in $/ \mathrm{kpì} / \rightarrow\left[\mathrm{kp}^{\mathrm{j}} \mathrm{i}\right]$ is changed so that it is nearer the palatal region. Urua (1990: 155 and 2000: 137) refers to this as palatal glide formation; which she says is similar to the labialisation process except that instead of added lip rounding to the consonant, the feature [- round] is added. Hume (1994) calls it coronalization because a velar stop becomes a coronal affricate for example $/ \mathrm{k} / \rightarrow[\mathrm{f}]$. Bhat (1978) tags it 'spirantization because in his example a consonant is spirantized in a palatalizing environment, for instance $/ \mathrm{r} / \rightarrow$ [s]. Telfer (2006) and Kim (2001) label it 'assibilation' because a dental stop /t/ changes to [ts] before a front vowel /i/. The various names brought in by different analysts depend on the extent or nature of the co-articulation. For instance, a consonant may totally shift its primary place of articulation while moving towards the palatal region of the vocal tract which Hume (1994), Telfer (2006) and Kim (2001) refer to it as 'full palatalization' where /k/ or $/ \mathrm{t} / \rightarrow$ [t] in the English phrase /don't ju/ $\rightarrow$ [dontjju] 'don't you'. Palatalization in Anaang is a case of secondary palatalization which involves a partial overlapping of a vowel feature on a consonant for instance $/ \mathrm{t} /$ or $/ \mathrm{d} / \rightarrow\left[\mathrm{t}^{\mathrm{j}}\right] /\left[\mathrm{d}^{\mathrm{j}}\right]$.

For palatalisation to occur there must be a target and a trigger. The targets in Anaang are the consonants /p, b, t, d, k, g, $\mathrm{kp}, \mathrm{m}, \mathrm{n}, \mathrm{f}, \mathrm{l}, \mathrm{w} /$, except the palatal consonants $/ \mathrm{f}$, $\mathrm{d}, \mathrm{n} /$, while the trigger must be the high front vowel $/ \mathrm{i} /$. Bateman (2007:272) says that the implicational hierarchy of palatalisation triggers is explained in terms of the gestural properties of the sound involved in palatalisation. It is evident that the basic conditions for trigger to occur are that the sound must be high and its constriction must be narrow. It is attested in other languages that the front vowel /e/ and palatal glide (or semi vowel) /j/ also triggers palatalisation.

The possibility for developing a trigger is illustrated in Figure 2 below. Horizontally, constriction location decreases from dorsal to palatal and vertically the constriction degree decreases from wide to narrow. According to Bateman (2007) the closer a sound is to both palatal and narrow, the more likely it is for it to be a trigger. This is why palatalisation involves either a shifting articulation towards the palatal region or acquiring a secondary palatal feature. These two extreme positions make /i/ the best trigger.

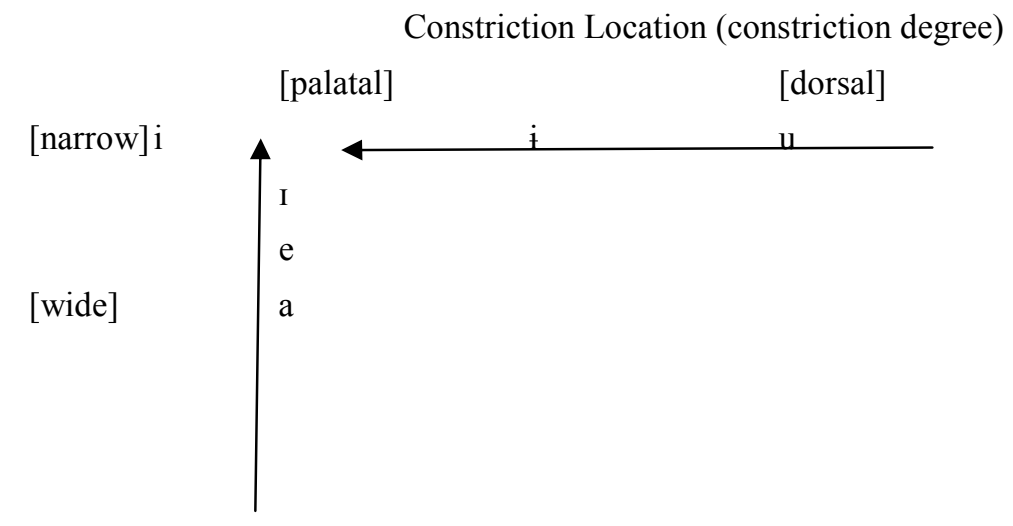

Figure 2. Palatalisation Triggers

Trigger could also be considered in terms of phonological locations. As phonology is specific to a language so is palatalisation. Palatalisation as an assimilatory process could be progressive or regressive. It is progressive palatalisation if the trigger precedes the target $/ \mathrm{j} /$, it is regressive if the trigger $/ \mathrm{g}^{\mathrm{j}} /$ follows the target. Bateman (2007:77) quips that the preferred but not the only, position of a trigger is to right of the target, resulting in regressive 
palatalization. Bhat (1978) equally confirms that the trigger primarily follows the target but also in some cases it precedes.

\subsection{Anaang Phonology}

The phonology of Anaang is made of the sound segments and the suprasegments. The segments comprise the consonants and the vowels which are structured into syllables. The exact number of segments in the language has not yet been fully established as the different scholars who work on the language establish sounds from their individual dialectal perspective. For example Ekpo (1994:83) proposed 17 phonemic consonants /p, b, t, d, k, gw , kp, m, n, y, n, f, tf, d子, l, w, s/. Ekpe (1996:62-63) equally came up with 17 phonemic consonant /p, t, d, k, gw, kp, m, n, n, f, tf, ds, l, w, в/. Udoh (1998:108) proposed 20 /p, b, t, d, k, gw , kp, m, n, y, n, f, tf, ds, l, w, к, R, j, s/. Michael (2000:24) suggested $22 / \mathrm{p}, \mathrm{b}, \mathrm{t}, \mathrm{d}, \mathrm{k}, \mathrm{k}^{\mathrm{w}}, \mathrm{g}^{\mathrm{w}}, \mathrm{kp}, \mathrm{m}, \mathrm{n}, \mathrm{y}, \mathrm{y}^{\mathrm{w}}, \mathrm{n}, \mathrm{f}, \mathrm{t}$, d $\mathrm{d}, \mathrm{f}, 1, \mathrm{j}, \mathrm{w}$, в /, while Michael and Obot (2001:42) presented 23 /p, b, t, $\mathrm{d}, \mathrm{k}, \mathrm{k}^{\mathrm{w}}, \mathrm{g}^{\mathrm{w}}, \mathrm{kp}, \mathrm{m}, \mathrm{n}, \mathrm{y}, \mathrm{g}^{\mathrm{w}}, \mathrm{n}, \mathrm{s}, \mathrm{f}, \mathrm{ff}, \mathrm{d}, \mathrm{r}, \mathrm{l}, \mathrm{j}, \mathrm{w}, \mathrm{\text {в}}, \mathrm{R} /$ and 6 vowels $/ \mathrm{a}$ e i o $\circ \mathrm{u} \mathrm{u} /$. Udoh (2012) establishes 27

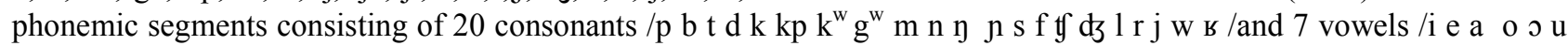
ut.

These segments are structured into syllables. The syllable structure defines the position of sounds within the syllable and what processes the sounds are subjected to. The Anaang syllable operates on three basic structures which are; $\mathrm{N}$ or $\mathrm{V}, \mathrm{CV}$, and CVC. All other structures are modifications from these basic forms. Thus, the syllable structure of Anaang appears in the following combinations as in 3 i-iv.

3.

i) $\quad \mathrm{N}$

ii) $\mathrm{V}$

/m-kpá /

[ṃ-kpá] 'death'

iii) $\quad \mathrm{CV}$

/ì -nó/

[ì -nó]

'thief'

iv) $\quad \mathrm{CVC}$

/mé/

[mé]

'endure'

/bén/

[bén]

'carry'

\section{Data Analysis and Findings}

The data presented below are the extract from our corpus that attests to palatalisation in Anaang. The foci of the research are to investigate the articulatory features of Anaang and how palatalisation is formed.

\subsection{Articulatory Features of Palatalisation In Anaang}

The articulatory features from our corpus show that; the target must be a consonants order than the palatal consonants. These consonant must be those that occur at word or syllable initial positions such as $/ \mathrm{b} \mathrm{t} \mathrm{d} \mathrm{k} \mathrm{kp} \mathrm{m} \mathrm{n} \mathrm{fl} \mathrm{w/.} \mathrm{A} \mathrm{sound} \mathrm{like}$ $/ \mathrm{p} /$ that occurs only word medially and finally cannot be palatalised in Anaang.

Another feature of palatalisation in Anaang is that assimilation is regressive as the trigger vocoid always comes after the target consonant. For example $/ \mathrm{i}-\mathrm{bit} / \rightarrow\left[\mathbf{i}^{\mathrm{i}} \mathrm{b} \mathbf{i} \mathrm{it}\right]$ 'drum', the assimilatory effect is leftward driven.

In Anaang, palatalisation is partial because there is no total shift in place of articulation, what is obtainable is coarticulation or a shift in feature from the trigger to the target consonant.

\subsection{Palatalisation Formation in Anaang}

Palatalisation in Anaang is formed basically on two conditions that there must be a trigger and a target. The trigger must be the high front vowel/i/, while the target must be any of the consonants except the palatal consonants $/ \mathrm{f}$ d $\mathrm{n} /$ because they are inherently palatals.

Structurally, palatalisation in Anaang is formed in CV syllable structure as presented in 4 below.

\section{Palatalisation in a CV Syllable Structure}

\begin{tabular}{|c|c|c|}
\hline /dí/ & {$\left[\mathrm{d}^{\mathrm{j}}{ }^{\prime}\right]$} & 'come' \\
\hline $\mathrm{CV}$ & $\mathrm{C}^{\mathrm{j}} \mathrm{V}$ & \\
\hline /é-dì/ & [é-d $\left.\mathrm{d}^{\mathrm{j}}\right]$ & 'pig' \\
\hline $\mathrm{V}-\mathrm{CV}$ & $\mathrm{V}-\mathrm{C}^{\mathrm{J}} \mathrm{V}$ & \\
\hline /é-tì/ & [é- $\left.-\mathrm{t}^{\mathrm{j}} \mathrm{i}\right]$ & 'good' \\
\hline $\mathrm{V}-\mathrm{CV}$ & $V-C^{J} V$ & \\
\hline /ù-dì/ & [ù- $\left.\mathrm{d}^{\mathrm{j}} \mathrm{i}\right]$ & 'grave' \\
\hline $\mathrm{V}-\mathrm{CV}$ & $\mathrm{V}-\mathrm{C}^{\mathrm{J}} \mathrm{V}$ & \\
\hline /à-ko'-tì/ & [à-ko'-t $\left.\mathrm{t}_{\mathrm{i}}\right]$ 'beans' & \\
\hline $\mathrm{V}-\mathrm{CV}-\mathrm{CV}$ & $\mathrm{V}-\mathrm{CV}-\mathrm{C}^{\mathrm{J}} \mathrm{V}$ & \\
\hline /kpì/ & {$\left[\mathrm{kp}^{\mathrm{j}} \mathrm{i}\right.$ ] } & 'cut' \\
\hline V & $\mathrm{C}^{\mathrm{J}} \mathrm{V}$ & \\
\hline /à-ti-dot/ & [à-t'ílídòt] & 'bitter le \\
\hline
\end{tabular}




V-CV-CVC V-C V-CVC

It can also be formed in a CVC syllable structure as illustrated in 5 below.

\section{Palatalisation in a CVC Syllable Structure}

\begin{tabular}{|c|c|c|}
\hline /ì-bit/ & {$\left[1-b^{j} \hat{i} t\right]$} & 'drum' \\
\hline V-CVC & $\mathrm{V}-\mathrm{C}^{\mathrm{J}} \mathrm{VC}$ & \\
\hline /é-nìn/ & [é-n'ì̀n] & 'elephant' \\
\hline $\mathrm{V}-\mathrm{CVC}$ & $\mathrm{V}-\mathrm{C}^{\mathrm{J}} \mathrm{VC}$ & \\
\hline /é-líp/ & [é-1'ípp] & 'twenty' \\
\hline $\mathrm{V}-\mathrm{CVC}$ & $\mathrm{V}-\mathrm{C}^{\mathrm{J}} \mathrm{VC}$ & \\
\hline /wíp/ & [wíp] & 'ask' \\
\hline CVC & $\mathrm{C}^{\mathrm{J}} \mathrm{VC}$ & \\
\hline /fik/ & [f'ík] & 'press' \\
\hline CVC & $\mathrm{C}^{\mathrm{J}} \mathrm{VC}$ & \\
\hline /á-fít/ & [á-f'ít] & 'faeces' \\
\hline $\mathrm{V}-\mathrm{CVC}$ & $\mathrm{V}-\mathrm{C}^{\mathrm{J}} \mathrm{VC}$ & \\
\hline /ú-líp/ & [ú-1'íp] & 'mushrom' \\
\hline $\mathrm{V}-\mathrm{CVC}$ & $\mathrm{V}-\mathrm{C}^{\mathrm{J}} \mathrm{VC}$ & \\
\hline
\end{tabular}

\section{Findings \& Conclusion}

The findings of the investigation show that palatalisation in Anaang is formed when a non-palatal consonant is followed be a high front vowel [i]. For palatalisation to occur there must be a target which is usually a non palatal consonant and a trigger which must be a high front vowel. Palatalisation in Anaang involves partial assimilation as there is no total shift in place feature, but an overlap in internal spatio-temporal organisation.

Palatalisation is an articulatory assimilation process whereby a non-palatal consonant absorbs the feature of palatal sound, mostly a high front vowel $/ \mathrm{i} /$. The presence of palatalisation in the palatals $/ \mathfrak{t}, \mathrm{d}, \mathrm{j} /$ are implicit, thus palatal sounds do not undergo palatalisation. Palatalisation as a phonological process is language specific, and in Anaang there is no full palatalisation rather what is obtainable is partial or Coarticulation that involves overlapping of features between the trigger and the target. Structurally, palatalisation in Anaang is constraint by the syllable structure. It can only occur in a CV or CVC syllable structure.

\section{References}

Bateman, N. (2007). Palatalisation in moldavian verbs: centrality of the infinitive base. LSRL 37, Pittsburgh, PA. Bhat, D.N.S (1978). A general study of palatalisation. Universals of Human Language, Greenberg ed, 47-92.

Browman, C. \& Goldstein, L. (1990). Tiers in articulatory phonology, with some implications for casual speech. In Papers in Laboratory Phonology. Kingston, J \& Beckman, M. (eds), pp.341-397. Cambridge: Cambridge University Press.

Clark, J. \& Yallop, C. (1990). An introduction to phonetics and phonology U. K.: Basil

Connell, B.A. (1991). Phonetic aspects of the lower cross languages and their implications for sound change. Ph.D. Dissertation, University of Edinburgh

Egbokhare, F. (2002). Introductory phonetics. Ibadan: Quasar and Language Solutions.

Ekpe, M.B. (2000). The phonological problems of Ibibio speakers of English as second language. M. A. Thesis. University of Lagos, Nigeria.

Ekpe, M. B. (1996). Comparative phonology of Anaang dialect: a case study of Oruk-Anam and Ikot-Ekpene. B. A. Project (Unpublished): The University of Calabar, Nigeria.

Greenberg, J. H. (1963). The languages of Africa. Bloomington: Indiana University. Mouton \& Co.

Johnson, Keith (2003). Acoustic and auditory phonetics. London: Blackwell Publishing Ltd

Kim, H. 2001. A phonologically based account of phonological stop assibilation. Phonology 18, 81-108.

Kochetov, A.(2002). Production, perception and emergent phonotactic patterns. Routledge

Michael, I. \& Obot, J. (2001). The orthography of Annang language. Calabar: Soturies Communications Ltd.

Michael, I. (2000). Assimilatory and syllable structure in Anaang. M.A Thesis, University of Uyo.

Telfer, C. (2006). Coronalisation as assimilation. Ph.D Dissertation, Calgary, Alberta

Urua, E. E. (1990). Aspects of Ibibio phonology and morphology: Unpublished Ph. D. Thesis, University Of Ibadan.

Urua, E.E. (2000). Ibibio phonetics and phonology.CASAS: Cape Town, South Africa. 